\title{
Identification of 'Ubá' mango tree zygotic and nucellar seedlings using ISSR markers ${ }^{1}$
}

\author{
Aline Rocha², Tânia Maria Fernandes Salomão ${ }^{3}$, Dalmo Lopes de Siqueira ${ }^{4}$, Cosme Damião Cruz ${ }^{5}$, \\ Luiz Carlos Chamhum Salomão ${ }^{4}$ \\ http://dx.doi.org/10.1590/0034-737X201461040001
}

\begin{abstract}
Polyembryonic seeds are characterized by the development of over one embryo in the same seed, which can be zygotic and nucellar. The objective of this work was to identify the genetic origin, whether zygotic or nucellar, of seedlings of polyembryonic seeds of 'Ubá' mango tree using ISSR markers, and relating them with the vigor of the seedlings. Thus, mangos were harvested in Visconde do Rio Branco (accession 102) and Ubá (accessions 112, 138, 152 and 159), whose seeds were germinated in plastic trays filled with washed sand. Fifty days after sowing, seedlings from five seeds of each one of the accessions 102,112, 138, 159 and from 10 seeds of the accession 152, were analyzed. These sseedlings were characterized and evaluated for plant height, stem circumference and mass of fresh aerial part and the most vigorous seedling was the one displaying at least two of these traits higher than the other seedlings from seed. Leaves were collected for genomic DNA extraction, which was amplified using seven ISSR primers previously selected based on the amplification profile and considering the number and resolution of fragments. Zygotic seedlings were found in 18 seeds, which were the most vigorous in six seeds. The results evidenced the existence of genetic variability in orchards using seedlings grown from seeds, because the farmer usually uses the most vigorous ones, assuming that this is of nucellar origin. These results also indicate that the most vigorous seedling are not always nucellar, inasmuch as of $20 \%$ of the total seeds evaluated, the zygotic seedling was the most vigorous.
\end{abstract}

Key words: Mangifera indica, polyembryony, rootstock, mass selection.

\section{RESUMO}

\section{Identificação de plântulas zigóticas e nucelares oriundas de sementes de mangueira 'Ubá' por meio de marcadores ISSR}

Sementes poliembriônicas são caracterizadas pelo desenvolvimento de mais de um embrião na mesma semente, que podem ser zigóticos ou nucelares. Neste trabalho, objetivou-se identificar a origem genética, se zigótica ou nucelar, de plântulas oriundas de sementes poliembriônicas de mangueira 'Ubá', utilizando-se marcadores moleculares ISSR, relacionando-a com o vigor das plântulas. Para isto, coletaram-se mangas, em Visconde do Rio Branco (acesso 102) e Ubá (acessos 112, 138, 152 e 159), das quais as sementes foram germinadas, em bandejas plásticas, com areia lavada. Cinquenta dias após a semeadura foram analisadas plântulas de cinco sementes, de cada um dos acessos

Received: 04/10/2013; Approved: 02/06/2014

${ }^{1}$ This paper is part of the first author's doctorate thesis.

${ }^{2}$ Agronomist, Doctor of Science. Instituto Federal de Educação, Ciência e Tecnologia Sertão Pernambucano, Campus Petrolina, Zona Rural, Petrolina, Pernambuco, Brazil. rochaline@ hotmail.com

${ }_{3}^{3}$ Pharmacist-Biochemist, Doctor of Science. Departamento de Biologia Geral, Universidade Federal de Viçosa, Campus Viçosa, Avenida Peter Henry Rolfs, s/n, 36570-000, Viçosa, Minas Gerais, Brazil. fernands@ufv.br

${ }^{4}$ Agronomist, Doctor of Science. Departamento de Fitotecnia, Universidade Federal de Viçosa, Campus Viçosa, Avenida Peter Henry Rolfs, s/n, 36570-000, Viçosa, Minas Gerais, Brazil.1salomao@ufv.br (autor para correspondência).

${ }^{5}$ Agronomist, Doctor of Science. Departamento de Biologia Geral, Universidade Federal de Viçosa, Campus Viçosa, Avenida Peter Henry Rolfs, s/n, 36570-000, Viçosa, Minas Gerais, Brazil.cdcruz@ufv.br 
102, 112, 138 e 159 e de 10 sementes do acesso 152. As plântulas foram caracterizadas e avaliadas quanto à altura, à circunferência do caule e à massa fresca da parte aérea e considerou-se a plântula mais vigorosa aquela que apresentasse pelo menos duas destas medidas superiores às das demais plântulas da semente. Folhas foram coletadas para extração de DNA genômico, que foi amplificado com sete primers ISSR, previamente selecionados com base no perfil de amplificação e considerando-se o número e a resolução dos fragmentos. Observou-se a presença de plântulas zigóticas em 18 sementes, que foram as mais vigorosas em seis sementes. Isso evidencia a existência de variabilidade em pomares que utilizam mudas oriundas de sementes, pois o produtor rural normalmente utiliza a plântula mais vigorosa, considerando que esta seja de origem nucelar. Esses resultados indicam que a plântula mais vigorosa nem sempre é a nucelar, pois, em $20 \%$ das sementes avaliadas, a plântula zigótica foi a mais vigorosa.

Palavras-chave: Mangifera indica, poliembrionia, porta-enxerto, seleção massal.

\section{INTRODUCTION}

The 'Ubá' mango is produced in Zona da Mata, in the state of Minas Gerais and it is of great importance to the juice and pulp industry and for in natura consumption in this region. Moreover, their polyembrionic seeds are used for rootstocks production.

Polyembryony is characterized by the development of more than one embryo in a single seed, and one may be zygotic and the others, nucellar (Mng'omba et al., 2010; Ravishankar et al., 2004), or all may be nucellar (Degani et al., 1993). Borges (1997) obtained an average of $6.40 \pm 1.81$ embryos per seed in 'Ubá' mangos. This trait is genetically controlled, and in mangos, it is due to a single dominant gene (Aron et al. 1998). The number of seedlings per seed varies with the cultivar (Cordeiro et al., 2006) and environmental conditions (AndradeRodríguez et al., 2004; 2005).

The nucellar embryos in mango trees are formed from the nucellar tissue that covers the embryo sac, and the seedlings originated from these embryos are genetically identical to the parent plant (Aron et al., 1998). However, the zygotic embryo is derived from fertilization by selfpollination or by cross-pollination.

The seedlings from nucellar embryos are preferred by nursery growers for the production of rootstocks because the outcome of using them is evener orchards (Rao et al., 2008). However, the zygotic embryo is the objective in breeding programs for the selection of superior genotypes and variability achievement.

The identification of seedlings derived from nucellar embryos by morphological criteria is not possible or difficult to be performed (Desai, 2004). Thus, the use of molecular or isoenzymatic markers is necessary to make the distinction. Generally, seedling producers use the most vigorous seedling from each seed for the production of rootstocks, however the nucellar seedling is not always the most vigouros, which results in uneven orchards. In 'Rosinha' mangos, $90 \%$ of the most vigorous seedlings from seeds collected in 2002 and 2003 were of zygotic origin, while seedlings from seeds harvested in 2004 were mostly of nucellar origin, indicating no relationship between the type of embryo and seedling size (Cordeiro et al., 2005).

Because of the difficulty in selecting nucellar seedlings in seeds of polyembrionic mangos using morphological characteristics, several authors have been using genetic markers, such as isoenzymes (Degani et al., 1993) and RAPD (Lamb et al., 2006) to identify zygotic and nucellar embryos. However, seedling producers find difficulties in identifying these markers and continue choosing plants according to their morphological characteristics. To make identification of zygotic seedlings an easy task, 'Ubá' mango seedling producers see the need to check if morphological characteristics (plant vigor) are related to their genetic origin.

The objective of this work was to identify the genetic origin, zygotic or nucellar of seedlings from 'Ubá' mango polyembryonic seeds by using ISSR molecular markers, relating it to the seedling vigor.

\section{MATERIALAND METHODS}

\section{Plant material}

Fruits and leaves of five accessions (102, 112, 138, 152 and 159) of 'Ubá' mango, obtained in Visconde do Rio Branco and Ubá, state of Minas Gerais, comprising the Germplasm Bank of the Federal University of Viçosa, were collected between 13 and 23 November, 2006. The fruits with green peels were harvested and allowed to ripen at room temperature. After that, their pulps were extracted and the seeds were washed in drinkable water and dried for three days outdoor. After the removal of the endocarp, seeds were treated with the fungicide Captan ${ }^{\circledR}$ at a dose of $2.4 \mathrm{~g} / \mathrm{kg}$ of seed, sown in medium 
texture washed river sand, and maintained in a greenhouse for 50 days. After this period, the seedlings from each seed were counted and then identified and evaluated for stem height $(\mathrm{cm})$ measured from the soil line, stem circumference $(\mathrm{mm})$, measured $2 \mathrm{~cm}$ above the soil line, and as fresh weight of the aerial part $(\mathrm{g})$, measured by weighing the plants on a $0.1 \mathrm{~g}$ accuracy scale. The leaves were collected for DNA extraction and analysis. For this, seedlings of five seeds of accessions 102, 112, 138, 159 , and of 10 seeds of accessions 152, totaling 117 seedlings (average of 3.9 seedlings per seed) were used.

\section{Seedlings vigor determination}

Height, stem circumference and fresh mass of the aerial part of seedlings were all measured to determine vigor. Data were evaluated using descriptive statistics and the most vigorous plant per seed was the one presenting at least two of the measures above with higher values than the ones found in other seedling of the same seed.

\section{DNA Extraction}

DNAs of 117 seedlings and their respective motherplants (accessions 102, 112, 138, 152 and 159) were extracted according to Gonzalez et al. (2002) with some modifications. Two hundred milligrams of leaves were macerated with liquid nitrogen in a porcelain mortar, until they reached powder condition. To this macerated, 800 $\mu \mathrm{L}$ of extraction buffer (2\% CTAB, $1.4 \mathrm{M} \mathrm{NaCl}, 20 \mathrm{mM}$ EDTA, 100 mM Tris-HCl, 0.4\% $\beta$-mercaptoethanol, $1 \%$ PVP, and $20 \mathrm{mM}$ sodium metabisulfite). The resulting mixture was transferred to $1.5 \mathrm{~mL}$ microtubes. These were incubated in a water bath for $30 \mathrm{~min}$ at $65^{\circ} \mathrm{C}$, and stirred every $10 \mathrm{~min}$. After incubation, deproteinization was carried out by adding $600 \mu \mathrm{L}$ of chloroform:isoamyl alcohol at a ratio of $24: 1$ and stirred for $10 \mathrm{~min}$. After centrifugation at $16,000 x \mathrm{~g}$ for $5 \mathrm{~min}$, the supernatant was transferred to another $1.5 \mathrm{~mL}$ microtube, and a new deproteinization was performed. After that, the nucleic acids (DNA and RNA) were precipitated by adding 600 $\mu \mathrm{l}$ of cold isopropanol and $150 \mu \mathrm{L}$ of $2.5 \mathrm{M}$ ammonium acetate and maintained for at least $2 \mathrm{~h}$ in a freezer at $20^{\circ} \mathrm{C}$. After centrifugation at $16,000 \mathrm{xg}$ for $30 \mathrm{~min}$, the supernatant was discarded, the pellet washed twice in $70 \%$ ethanol and dried at room temperature. The nucleic acids were resuspended in $100 \mu \mathrm{L} \mathrm{TE}(10 \mathrm{mM}$ Tris- $\mathrm{HCl}$, pH 8.0; 1 mM EDTA pH 8.0). For RNA removal, the nucleic acid solution was treated with RNAase $(10 \mathrm{mg} /$ $\mathrm{ml}$ ), by adding $3 \mu \mathrm{L}$ in every $100 \mu \mathrm{L}$ sample, incubated at $37{ }^{\circ} \mathrm{C}$ for $30 \mathrm{~min}$. The resulting DNA was stored in a freezer at $-20{ }^{\circ} \mathrm{C}$. Then, the samples were submitted to electrophoresis on $0.8 \%$ agarose gel containing $0.2 \mu \mathrm{g}$ / $\mathrm{mL}$ of ethidium bromide to quantify and to check the integrity and purity of the DNA.

\section{DNAAmplification}

For DNA amplification, 96 primers were tested, of which 93 of the \#9 Set of UBC (University of British Columbia), one (Terry) used by Gonzalez et al. (2002) and the other two (C and D), designed for bees in the Laboratory of Biophysics and Molecular Biology of the Federal University of Viçosa. Based on the amplification pattern, 19 primers were selected for which pairing temperatures and PCR reactions were optimized. Of these, seven ISSR (Inter simple sequence repeat) primers were selected $(816,823,825,891$, $899, \mathrm{D}$ and Terry) on the basis of the number and resolution of fragments and excluding primers with few fragments and those that presented weak and nonspecific fragments (Table 1). According to the primer used, the reaction mixture for amplification consisted of different concentrations of reagents to obtain the greatest greater number of amplified fragments, yielding three amplification mixtures (AM), named A, B and C, adjusted according to Eiadthong et al. (1999) and to González et al. (2002). The reagents used in the amplification mixture A were the following: $5.0 \mu \mathrm{L} 5 \mathrm{X}$ Buffer Colorless Reaction Buffer of GoTaq ${ }^{\circledR}$ Flexi DNA Polymerase; $1.5 \mu \mathrm{L} 25 \mathrm{mM} \mathrm{MgCl}$; $1.0 \mu \mathrm{L}$ Deoxy nucleotides (dNTP) $100 \mu \mathrm{M} ; 0.2 \mu \mathrm{L}$ plolimerase DNA GoTaq ${ }^{\circledR}$ Flexi DNA Polymerase (Promega) - 5U/ $\mu \mathrm{L}, 2.0$ $\mu \mathrm{L}$ Primer $5 \mu \mathrm{M}$; $3.0 \mu \mathrm{L}$ genomic DNA $17 \eta \mathrm{g} / \mu \mathrm{L}$ and

Table 1. Primers used and respective sequences, number of amplified fragments, annealing temperatures (Ta) and amplification mixture (AM)

\begin{tabular}{lcccc}
\hline Primer & 5'- 3'Sequence & No. of fragments & Ta $\left({ }^{\circ} \mathbf{C}\right)$ & $\mathbf{A M}^{\mathbf{1}}$ \\
\hline 816 & CACACACACACACACAT & 9 & 50 & $\mathrm{~A}$ \\
823 & TCTCTCTCTCTCTCTCC & 5 & 53 & $\mathrm{~A}$ \\
825 & ACACACACACACACACT & 8 & 53 & $\mathrm{~B}$ \\
$891^{2}$ & HVHTGTGTGTGTGTGTG & 10 & 40 & $\mathrm{~B}$ \\
899 & CATGGTGTTGGTCATTGTTCCA & 3 & 53 & $\mathrm{~B}$ \\
$\mathrm{D}^{2}$ & HVHCACCACCACCACCACT & 5 & 53 & $\mathrm{~B}$ \\
Terry $^{2}$ & GTGGTGGTGGTGRC & 7 & 53 & $\mathrm{C}$ \\
\hline
\end{tabular}

${ }^{1}$ According to Table $2,{ }^{2}$ Primers anchored at 5 ' or 3' extremities; $\mathrm{R}=(\mathrm{A}$ or $\mathrm{G}), \mathrm{H}=(\mathrm{A}, \mathrm{C}$ or $\mathrm{T})$; and $\mathrm{V}=(\mathrm{A}, \mathrm{C}$ or G). 
ultrapure water to volume of $20 \mu \mathrm{L}$. For the B amplification mixture, the reagents used were $4.0 \mu \mathrm{L}$ Buffer 5X Colorless Reaction Buffer of GoTaq ${ }^{\circledR}$ Flexi DNA Polymerase, $1.2 \mu \mathrm{L}$ of $25 \mathrm{mM} \mathrm{MgCl}_{2} ; 2.5 \mu \mathrm{L}$ Deoxy-nucleotide (dNTP) $100 \mu \mathrm{L} ; 0.2 \mu \mathrm{L}$ polymerase DNA GoTaq ${ }^{\circledR}$ Flexi DNA Polymerase (Promega) - 5U/ $\mu \mathrm{L} ; 5.0 \mu \mathrm{L}$ Primer; $3.0 \mu \mathrm{L}$ genomic DNA $17 \eta \mathrm{g} / \mu \mathrm{L}$ and ultrapure water up to a reaction volume of $25 \mu \mathrm{L}$. The amplification mixture $\mathrm{C}$ differed from the amplification mixture B only in relation to the amount of primer used in the reaction, which was $2.0 \mu \mathrm{L}$ Primer $5 \mu \mathrm{L}$.

The DNA amplification reaction was carried out in a PTC-100 thermocycler (MJ Research Inc.) as follows: $3 \mathrm{~min}$ at $94{ }^{\circ} \mathrm{C}$ (initial denaturation) followed by 401 -min cycles at $92{ }^{\circ} \mathrm{C}$ (denaturation); $2 \mathrm{~min}$ at annealing temperature (variable according to the primer used; Table 1); 2 min at $72{ }^{\circ} \mathrm{C}$, and a final extension step of $7 \mathrm{~min}$ at $72{ }^{\circ} \mathrm{C}$.

The amplification products were separated by agarose gel electrophoresis (Agarose for Routine Use SIGMA, A9539 - 500G) at $1.5 \%$, visualized by staining with ethidium bromide $(0.2 \mu \mathrm{g} / \mathrm{mL})$ and photorecorded under ultraviolet light, using AlphaDigiDoc system.

\section{Data analysis}

For data analysis, the ISSR patterns displayed by seedlings in relation to the standard of the mother plant were compared for each of the primers used. Amplification profiles that did not present dubious amplified fragments (weak fragments and with no reproducibility) were used, while those with dubious fragments were excluded. Seedlings with polymorphism standard for ISSR marker in three primers at least, when compared to the mother plants, were considered as of zygotic origin, as recommended by Novy et al. (1994). This criterion was adopted because Novy et al. (1994) have worked with RAPD markers, which, like the ISSR, are dominant and therefore do not allow the separation of heterozygotes from dominant homozygous.

\section{RESULTS AND DISCUSSION}

Of the five seeds of accession 102, which originated 21 seedlings, zygotic seedlings were found in seeds 2,4 and 5 (Table 2), representing $60 \%$ of seeds evaluated. Regarding seed 2, the zygotic seedling displayed intermediate vigor, but in was the most vigorous seed 4 and the least vigorous in the seed 5 (Table 3). No relationship between seedling vigor and its origin is found, which can be explained by the fact that zygotic seedlings of poliembryonic cultivars are indicated for being close to the basal region of the seed and degenerate themselves or because they do not develop well because of competition with the nucellar seedlings (Srivastava et al. 1988). On the other hand, Cordeiro et al. (2006) found that zygotic seedling may be the strongest due to the heterosis effect, and it can be found in positions far from the basal one, even though this position favors fertilization in the embryo sac.

In some seedlings, two polymorphic primers were found, which made scientists think whether or not they were zygotic. However, by taking into account the principle of Novy et al. (1994), who working with RAPD markers, dominant as ISSR, for instance, in cranberry plants [Vaccinium macrocarpon (Ait.) Pursh], found that polymorphism in three primers would be needed to separate these plants. In addition, three ISSR primers of nine primers used to assess the genetic diversity of 102 accessions of 'Ubá' mango tree, could differentiate between the two accessions that presented genetic distance, by the Jaccard index, the $\mathrm{d}_{\mathrm{ii}}=0.07$ (Rocha et al., 2011). Thus, they were considered as nucellar seedlings.

Zygotic seedling were found in three seeds (2, 4 and 5 ), that is, $60 \%$ of the five seeds analyzed in accession 112 which yielded a total of 26 seedlings (Table 2 ). The zygotic seedlings found in seeds 2 and 5 were the most vigorous whereas vigor was intermediate in seed 4 (Table 3 ). It was found by the band profile the presence of two genetically different zygotic seedlings in seed 2 .

In citrus, whose seeds are also polyembrionic, a type of polyembryony caused by the occurrence of more than a normal gametophyte in the same egg was found (Bacchi, 1944). This may explain the occurrence of two zygotic embryos in the same seed and the fact that they are genetically different due the possibility of fertilization of both gametophytes.

The five evaluated seeds of accession 138 produced a total of 19 seedlings. A zygotic seedling was found in seeds 3 and 4 (40\% of seeds evaluated) and in none of them, the zygotic seedling was the most vigorous (Tables 2 and 3). The fact that the zygotic seedling is not always the most vigorous disagrees with the results obtained by Degani et al. (1993), who found that the average mass of zygotic seedlings was higher than the nucellar seedlings in 'Turpentine' and '13-1' mango trees.

Of the ten evaluated seeds of accession 152, for a total of 30 seedlings, zygotic seedlings were obtained in seven seeds $(1,2,4,6,7,8$ and 9), corresponding to $70 \%$ of analyzed seeds (Table 2 ). Seed 8 presented two zygotic seedlings with similar fragments profile, but it cannot be stated that they are genetically identical, since the ISSR marker is dominant and does not allow separate dominant homozygous from heterozygous. Zygotic seedling was the most vigorous only in seed 1 (Tables 2 and 3). 
Table 2. Seedlings evaluated from 30 seeds (Sem) of five accessions (Aces) of 'Ubá' mango trees with their respective number of polyphormic (PP) and monophormic (PM) primers, used to identify zygotic and nucellar seedlings by ISSR markers

\begin{tabular}{|c|c|c|c|c|c|c|c|c|c|}
\hline \multirow{3}{*}{ Aces } & \multirow{3}{*}{ Sem } & \multirow{3}{*}{ Seedling } & $\mathbf{P P}$ & PM & \multirow{3}{*}{ Aces } & \multirow{3}{*}{ Sem } & \multirow{3}{*}{ Seedling } & $\mathbf{P P}$ & \multirow{3}{*}{$\begin{array}{c}\text { PM } \\
\text { Seedling } \\
1,2,3,4,5,6\end{array}$} \\
\hline & & & Seedling & Seedling & & & & Seedling & \\
\hline & & & $1,2,3,4,5,6,7$ & $1,2,3,4,5,6,7$ & & & & $1,2,3,4,5,6$ & \\
\hline \multirow{5}{*}{102} & 1 & $\underline{\mathbf{1}}, 2$ & 0,0 & 7,7 & \multirow{10}{*}{152} & 1 & $\underline{1}, 2$ & $\underline{4}, 0$ & 0,7 \\
\hline & 2 & $\underline{\mathbf{1}}, 2,3,4,5,6,7$ & $0,0, \underline{\mathbf{6}}, 0,0,2,2$ & $7,7,1,7,7,5,5$ & & 2 & $\underline{\mathbf{1}}, 2,3$ & $0,0, \underline{\mathbf{5}}$ & $7,7,2$ \\
\hline & 3 & $\underline{\mathbf{1}}, 2,3,4$ & $0,0,0,0$ & $7,7,7,7$ & & 3 & $\underline{\mathbf{1}}, 2$ & 0,0 & 6,6 \\
\hline & 4 & $\underline{\mathbf{1}}, 2,3,4$ & $\underline{\mathbf{3}}, 0,2,1$ & $4,7,4,6$ & & 4 & $1, \underline{\mathbf{2}}, 3$ & $0,0, \underline{4}$ & $7,7,1$ \\
\hline & 5 & $\underline{\mathbf{1}}, 2,3,4$ & $0,0,0, \underline{\mathbf{3}}$ & $7,6,7,4$ & & 5 & $\underline{\mathbf{1}}, \overline{2}$ & 0,2 & 6,4 \\
\hline \multirow{5}{*}{112} & 1 & $1, \underline{\mathbf{2}}, 3,4,5,6$ & $0,0,0,1,1,2$ & $7,7,7,6,6,5$ & & 6 & $\underline{\mathbf{1}}, 2,3$ & $0,2, \underline{\mathbf{3}}$ & $7,5,1$ \\
\hline & 2 & $1, \underline{\mathbf{2}}, 3,4,5,6$ & $\underline{\mathbf{3}}, \underline{\mathbf{3}}, 0,0,0,0$ & $3,1,7,7,7,7$ & & 7 & $\underline{\mathbf{1}}, 2,3,4,5,6$ & $0,0, \underline{\mathbf{3}}, 0,0,0$ & $7,7,3,7,7,7$ \\
\hline & 3 & $\underline{\mathbf{1}}, 2,3,4$ & $1,0,1,1$ & $6,6,6,6$ & & 8 & $\underline{\mathbf{1}}, 2,3,4$ & $1,1, \underline{\mathbf{5}}, \underline{\mathbf{4}}$ & $6,4,2,2$ \\
\hline & 4 & $\underline{\mathbf{1}}, 2,3,4,5$ & $0, \underline{\mathbf{3}}, 0,0,1$ & $7,4,7,7,6$ & & 9 & $\underline{\mathbf{1}}, 2$ & $0, \underline{4}$ & 7,1 \\
\hline & 5 & $\underline{\mathbf{1}}, 2,3,4,5$ & $\underline{\mathbf{3}}, 1,0,0,0$ & $4,6,7,7,7$ & & 10 & $\underline{\mathbf{1}}, 2,3$ & $0,2,0$ & $7,5,7$ \\
\hline \multirow{5}{*}{138} & 1 & $1, \underline{\mathbf{2}}, 3$ & $0,0,2$ & $7,7,5$ & \multirow{5}{*}{159} & 1 & $\underline{\mathbf{1}}, 2,3$ & $0,0,1$ & $7,7,6$ \\
\hline & 2 & $\underline{\mathbf{1}}, 2,3,4,5$ & $0,1,0,1,1$ & $7,6,7,6,6$ & & 2 & $\underline{\mathbf{1}}, 2,3,4$ & $\underline{\mathbf{3}}, 0,0,0$ & $4,7,7,7$ \\
\hline & 3 & $1, \underline{\mathbf{2}}, 3,4$ & $0,0,0, \underline{4}$ & $7,7,7,2$ & & 3 & $\underline{\mathbf{1}}, 2,3,4$ & $0,0,0,1$ & $7,7,7,6$ \\
\hline & 4 & $\underline{\mathbf{1}}, 2,3,4$ & $0,1,1, \underline{4}$ & $7,6,6,2$ & & 4 & $\underline{\mathbf{1}}, 2,3,4,5,6$ & $0,2,0,1,0, \underline{\mathbf{6}}$ & $7,4,7,6,7,0$ \\
\hline & 5 & $\underline{\mathbf{1}}, 2,3$ & $0,0,2$ & $7,7,4$ & & 5 & $\underline{\mathbf{1}}, 2,3,4$ & $\underline{\mathbf{4}}, 0,1,0$ & $1,7,6,7$ \\
\hline
\end{tabular}

Numbers underlined on the seedling column are the most vigorous seedling and on the polyphormic primers columns they correspond to the seedlings from zygotic embryos. 


$152 \quad 4$
6
6
7
8
9
10
1
2

\begin{tabular}{|c|c|c|c|c|c|c|}
\hline \multicolumn{7}{|c|}{ Height (cm) } \\
\hline \multirow{2}{*}{$\begin{array}{l}\text { Jumber of } \\
\text { eedlings }{ }^{1}\end{array}$} & & & & dli & & \\
\hline & 1 & 2 & 3 & 4 & 5 & 6 \\
\hline
\end{tabular}

\begin{tabular}{cccccccc}
\multicolumn{7}{c}{ Diameter $(\mathrm{mm})$} & \\
\cline { 1 - 7 } &
\end{tabular}

\begin{tabular}{lllllll}
\multicolumn{8}{c}{ FM (g) } \\
\hline \multicolumn{7}{c}{ Seedling } \\
\hline $\mathbf{1}$ & $\mathbf{2}$ & $\mathbf{3}$ & $\mathbf{4}$ & $\mathbf{5}$ & $\mathbf{6}$ & $\mathbf{7}$ \\
\hline $4.99 ;$ & 0.87 & & & &
\end{tabular}

$4.85 ; 2.52$

$2.57 ; 2.29 ; 2.30 ; 3.41 ; 2.77 ; 2.70 ; 2.10$

$1.91 ; 1.46 ; 0.96 ; 0.90 ; 0.80 ; 0.62 ; 0.35$

$\begin{array}{rrrrrrr}9.0 ; & 9.7 ; & 8.1 ; & 9.4 ; 8.5 ; \quad 9.1 ; \quad 5.5 & 2.57 ; 2.29 ; 2.30 ; 3.41 ; 2 \\ 12.5 ; 11.4 ; & 9.3 ; & 5.9 & & 3.07 ; 2.07 ; 2.23 ; 2.39\end{array}$

$13.0 ; \quad 9.4 ; 9.9 ; \quad 7.3$

$3.29 ; 2.66 ; 2.69 ; 2.42$

$1.88 ; 1.22 ; 0.65 ; 0.45$

$2.19 ; 1.22 ; 1.05 ; 0.67$

$17.0 ; 10.0 ; \quad 8.0 ; \quad 6.9$

$3.88 ; 2.46 ; 3.02 ; 2.23$

$5.11 ; 1.31 ; 0.64 ; 0.54$

$6.8 ; 17.7 ; 14.2 ; 12.7 ; 9.7 ; 4.4$

$3.55 ; 3.57 ; 3.44 ; 2.67 ; 3.50 ; 1.77$

$3.82 ; 2.96 ; 3.80 ; 1.26 ; 0.58 ; 0.31$

$11.0 ; 14.0 ; 12.2 ; 8.4$

$13.2 ; 12.6 ; 9.0 ; 9.6 ; 6.2$

$2.70 ; 2.58 ; 2.47 ; 1.78$

$2.32 ; 2.20 ; 1.16 ; 1.23 ; 0.73 ; 0.34$

$2.14 ; 1.68 ; 1.05 ; 0.60$

$3.54 ; 2.46 ; 2.95 ; 2.37 ; 1.81$

$2.52 ; 1.14 ; 1.55 ; 0.89 ; 0.22$

$11.0 ; \quad 9.6 ; 10.1 ; 9.0 ; 8.8$

$2.48 ; 2.14 ; 2.23 ; 2.32 ; 1.90$

$1.29 ; 1.30 ; 1.08 ; 0.82 ; 0.51$

$10.7 ; 10.2 ; 7.9$

$2.65 ; 2.85 ; 2.09$;

$15.3 ; 9.4 ; 7.1 ; 6.0 ; 7.3 \quad 4.39 ; 2.85 ; 2.08 ; 1.90 ; 1.85$

$1.94 ; 1.70 ; 0.62$

$12.5 ; 13.2 ; 4.0 ; 11.0$

$3.29 ; 3.78 ; 1.41 ; 3.62$

$4.50 ; 1.57 ; 0.68 ; 0.46 ; 0.33$

$13.7 ; 10.3 ; \quad 5.2 ; \quad 4.9$

$3.64 ; 2.40 ; 1.91 ; 1.56$

$1.86 ; 2.58 ; 0.37 ; 0.85$

$16.3 ; 10.5 ; 10.4$

$3.87 ; 2.49 ; 2.43$

$3.19 ; 1.24 ; 0.89$

$9.9 ; 8.6 ; 7.3 \quad 2.19 ; 3.10 ; 2.15$

$11.6 ; 5.7$

$10.4 ; 14.4 ; 4.2$

$13.8 ; 4.8$

$2.96 ; 1.97$

$2.56 ; 2.52 ; 1.23$

$3.11 ; 1.47$

$3.83 ; 2.57 ; 2.08$

$11.8 ; 10.7 ; 9.4 ; 4.8 ; 4.0 ; 2.1$

$2.88 ; 2.77 ; 2.25 ; 1.65 ; 1.45 ; 1.18$

$2.56 ; 1.90 ; 1.44 ; 1.43$

$2.20 ; 1.78$

$0.82 ; 0.33$

$0.86 ; 1.08 ; 0.62$

$2.05 ; 0.24$

$1.19 ; 1.12 ; 0.14$

$2.57 ; 0.26$

$4.13 ; 1.13 ; 0.57$

$10.4 ; \quad 6.8 ; \quad 5.0 ; \quad 4.8$

$7.5 ; \quad 5.3$

$3.98 ; 1.99 ; 1.44$

$1.87 ; 1.53 ; 1.25 ; 0.57 ; 0.28 ; 0.17$

$18.0 ; \quad 8.8 ; \quad 6.2$

$3.3 ; 12.5 ; 5.4$

$15.0 ; 10.0 ; 10.3 ; 7.5$

$4.03 ; 2.68 ; 1.57$

$1.61 ; 0.66 ; 0.22 ; 0.13$

$1.02 ; 0.53$

5,$02 ; 0,97 ; 0.24$

159

$15.1 ; 11.0 ; \quad 9.8 ; \quad 6.4$

$3.33 ; 2.14 ; 2.31 ; 1.94$

$3.32 ; 2.32 ; 2.54 ; 1.69$

$2.39 ; 1.34 ; 0.22$

$13.6 ; \quad 9.3 ; \quad 8.5 ; \quad 5.7 ; \quad 4.1 ; \quad 3.5$

$3.24 ; 2.38 ; 2.45 ; 2.21 ; 1.61 ; 1.09$

$3.04 ; 1.16 ; 0.78 ; 0.48$

$2.30 ; 1.47 ; 1.23 ; 0.43$

$10.0 ; 11.0 ; \quad 5.9 ; \quad 5.5$

$3.14 ; 2.44 ; 2.25 ; 2.11$

1.84; $0.73 ; 0.57 ; 0.47 ; 0.18 ; 0.16$

$2.41 ; 0.97 ; 0.59 ; 0.32$

${ }^{1}$ Number of seedlings of each seed. 
The two zygotic seedlings from seed 8 may have been generated by the "policaulismo" phenomenon. This phenomenon is found in mango trees and was reported by Pinto et al. (2002), or by polyembriony by cleavage, originated from the cleavage of the embryo, as seen in Vincetoxicum rossicum by Hotchkiss et al. (2008), or even by the occurrence of more than a normal gametophyte in the same egg (Bacchi, 1944).

Of the five evaluated seeds of accession 159, making a total of 21 seedlings, zygotic seedlings were found only in seeds 2, 4 and 5. Zygotic seedlings were the most vigorous in seeds 2 and 5, and they were the less vigours in seed 4 (Tables 2 and 3).

The presence of zygotic seedlings was found in 18 of the 30 evaluated seeds ( $60 \%$ of the evaluated seeds) and the zygotic seedling was the strongest in six seeds. These results indicated that the most vigorous seedling is not always genetically equal to the mother plant because the zygotic seedling was the most vigorous in $20 \%$ of the evaluated seeds.

The fact that the most vigorous seedling is not always nucellar together with the habit of farmers to always select the most vigorous seedlings for planting evidences the possibility of existence of genetic variability in orchards set from ungrafted seedlings and it helps explain the phenotypic differences found in the field. The same occurs in obtaining rootstocks because this small percentage of more vigorous zygotic embryos may contribute to the heterogeneity found in orchards, whose crown-cultivars are cloned. Degani et al. (1993) also found that there is no relationship between the position of the seedling in the seed and the embryo type when working with 'Turpentine' and '13-1' mango trees. The same was found by Andrade-Rodriguez et al. (2004) using RAPD markers in Citrus volkameriana.

The ISSR marker was useful as tool for the identification of the genetic origin of seedlings from 'Ubá' mango tree seeds. However, because it is a dominant marker, it did not allow identifying whether the zygotic seedlings were from self-pollination or cross-pollination since this marker does not allow the separation of the dominant homozygote from the heterozygote. Furthermore, it was not possible to conclude whether zygotic seedlings from the same seed are genetically identical.

\section{CONCLUSIONS}

Zygotic embryos can be the most vigorous in 'Ubá' mango tree polyembryonic seeds.

The presence of a more vigorous zygotic embryo than the nuclear results in genetic variability when the seed is used for the production of rootstocks and ungrafted seedlings.
The ISSR marker was useful as a tool for identifying the genetic origin of seedlings of 'Ubá' mango tree polyembryonic seeds. However, it did not allow identifying whether the zygotic seedlings were derived from self-pollination or cross-pollination and to state zygotic seedlings in the same seed as genetically identical; for this identification it is needed to use codominant markers.

\section{ACKNOWLEDGEMENTS}

To the Fundação de Amparo à Pesquisa do Estado de Minas Gerais (FAPEMIG), for granting scholarship and financing the 'Ubá' Mango Tree Breeding Project. To the Molecular Biology Laboratory in the General Biology Department of the Viçosa Federal University for supporting the molecular analyses.

\section{REFERENCES}

Andrade-Rodríguez M, Villegas-Monter A, Carrillo-Castañeda G \& García-Velázquez A (2004) Polyembryony and identification of Volkamerian lemon zygotic and nucellar seedlings using RAPD. Pesquisa Agropecuária Brasileira, 39:551-559.

Andrade-Rodríguez M, Villegas-Monter A, Gutiérrez-Espinosa MA, Carrillo-Castañeda G \& García-Velázquez A (2005) Polyembryony and RAPD markers for identification of zygotic and nucellar seedlings in citrus. Agrociência, 39:371-383.

Aron Y, Czosnek H, Gazit S \& Degani C (1998) Polyembryony in mango (Mangifera indica L.) is controlled by a single dominant gene. HortScience, 33:1241-1242.

Bacchi O (1944) Observações citológicas em citrus: III. Megasporogênese, fertilização e poliembrionia. Bragantia, 4:405-412.

Borges CAM (1997) Caracterização biométrica de sementes, germinação e crescimento de plântulas das mangueiras (Mangifera indica L.) 'Espada' e 'Ubá'. Dissertação de Mestrado. Universidade Federal de Viçosa, Viçosa. 122p.

Cordeiro MCR, Ramos VHV, Pinto ACQ, Fraga LMS, Dias JN \& Lopes GKB (2005) Identificação molecular da origem zigótica ou nucelar de plântulas de sementes poliembriônicas de manga 'Rosinha' com base em RAPD. In: $3^{\circ}$ Congresso Brasileiro de Melhoramento de Plantas, Gramado. Anais, Embrapa Trigo. CD-ROM.

Cordeiro MCR, Pinto ACQ, Ramos VHV, Faleiro FG \& Fraga LMS (2006) Identificação da origem genética de plântulas em sementes poliembriônicas de mangueira (Mangifera indica, L.) cv. Rosinha por meio de marcadores RAPD. Revista Brasileira de Fruticultura, 28:454-457.

Degani C, Cohen M, Reuveni O, El-Bastri R \& Gazit S (1993) Frequency and characteristics of zygotic seedlings from polyembryonic mango cultivars, determined using isozymes as genetic markers. Acta Horticulturae, 341:78-85.

Desai BB (2004) Seeds handbook: biology, production, processing and storage. $2^{\mathrm{a}} \mathrm{ed}$. New York, CRC Press. 787p.

Eiadthong W, Yonemori K, Sugiura A, Utsunomiya N \& Subhadrabandhu S (1999) Identification of mango cultivars of Thailand and evaluation of their genetic variation using the amplified fragments by simple sequence repeat - (SSR-) anchored primers. Scientia Horticulturae, 82:57-66.

González A, Coulson M \& Brettell R (2002) Development of DNA markers (ISSRs) in mango. Acta Horticulturae, 575:139-143. 
Hotchkiss EE, Ditommaso A, Brainard DC \& Mohler CL (2008) Survival and performance of the invasive vine Vincetoxicum rossicum (Apocynaceae) from seeds of different embryo number under two light environments. Disponível em: <http://www.amjbot.org/cgi/ content/full/95/4/447>. Acessado em: 07 de julho de 2010.

Mng'omba SA, Akinnifesi FK, Sileshi G \& Ajayi OC (2010) Rootstock growth and development for increased graft success of mango (Mangifera indica) in the nursery. Disponível em: <http:// www.academicjournals.org/AJB>. Acessado em: 20 de junho de 2010.

Novy RG, Kobak C, Goffreda J \& Vorsa N (1994) RAPDs identify varietal misclassification and regional divergende in cranberry (Vaccinium macrocarpon (Ait.) Pursh). Theoretical Applied Genetics, 88:10041010

Pinto ACQ, Souza VAB, Rosseto CJ, Ferreira FR \& Costa JG (2002) Melhoramento genético. In: Genú PJC \& Pinto ACQ (Eds.) A cultura da mangueira. Brasília, Embrapa Informação Tecnológica. p.51-92.
Rao MN, Soneji JR, Chen C, Huang S \& Gmitter Jr FG (2008) Characterization of zygotic and nucellar seedlings from sour orangelike citrus rootstock candidates using RAPD and EST-SSR markers. Tree Genetics \& Genomes, 4:113-124.

Ravishankar1 KV, Chandrashekara P, Sreedhara SA, Dinesh MR, Lalitha A \& Saiprasad GVS (2004) Diverse genetic bases of Indian polyembryonic and monoembryonic mango (Mangifera indica $\mathrm{L}$ ) cultivars. Current Science, 87:870-871.

Rocha A, Salomão LCC, Fernandes-Salomão TM, Cruz CD \& Siqueira DL (2011) Genetic Diversity of 'Uba'" Mango Tree Using ISSR Markers. Molecular Biotechnology, 50:108-113.

Srivastava KC, Rajput MS, Singh NP \& Lal B (1988) Rootstock studies in mango cv Dashehari. Acta Horticulturae, 231:216-219. 